\title{
The Political Role of the Patriarch in the Contemporary Middle East
}

\section{Summary}

This essay explores the relationship between religion and politics in the context of the Christian communities in the Middle East. The crisis of state framework is used to explain that as the spiritual leader of their communities, the heads of the Coptic Orthodox and Maronite churches - Patriarch Shenouda III and Patriarch Nasrallah Sfeir - have felt compelled to act as communal spokesmen in the absence of other credible political actors. It is argued that the lack of widespread political participation, failure of economic development and chronic insecurity in the Middle East have led to an environment where increased perception of vulnerability has allowed religion to retain social significance.

\section{Introduction}

In the Middle East today, religion is widely accepted as retaining its social significance in the region. The crisis of state thesis can be used to explain the apparent absence of the secularization process in this area of the developing world. Several states have delivered neither economic development nor meaningful political participation. In some cases, governments have failed in their basic duty to provide security to their citizens. Under these conditions, religious institutions are able to remain central to society, thus increasing the likelihood that religious leaders will be able to exercise a political role. The study of politicized religion has been adequately addressed concerning Islam and Judaism but little work has been undertaken concerning Christianity. In the Eastern Christian tradition, the patriarch as the head of the church has historically enjoyed a dual role as the spiritual and temporal leader of the community. This capacity still remains today. As the leading communal actor, the church has the potential to fill any leadership vacuum and can use its resources to strengthen the claim of the patriarch to be the political representative of the 
community at the expense of lay rivals. For the purpose of this study, the political role of the patriarch is defined as acting as the civil representative of the community and liasing between the community and the ruling authorities. It is not an attempt to take over the state or gain political power but instead, as throughout the centuries, to ensure the best means of survival for the community. By placing this discussion within the crisis of state framework, this essay will seek to explain why certain patriarchal churches exercise a significant political role, suggesting that patriarchal authority and the Islamic environment reinforces communal acceptance of the temporal power of the patriarch.

The two case studies selected for this research - the Coptic Orthodox and Maronite churches - demonstrate that under certain conditions, the patriarch can choose to reassert the political role of his office. Although the two churches represent different interpretations of the christological definitions that split the universal church in the fifth century, they share several key characteristics. Firstly, both evoke a distinct identity on the basis of faith yet are directly linked to a specific homeland - Egypt and Lebanon respectively. Secondly, both communities have pressing if different concerns as indigenous Christians in a turbulent regional environment dominated by another religion. Thirdly, since becoming the head of each church, Patriarch Shenouda III, Coptic Orthodox Patriarch of Alexandria and all Africa and Patriarch Nasrallah Boutros Sfeir, Patriarch of Antioch and all the East of the Maronites, have proven to be charismatic and influential figures in church and national affairs. Finally, the two case studies best represent the potential of Christian communities to have a political role in this region. While the Copts constitute only a small proportion of the Egyptian population (5-10 per cent), they are still the largest Christian community in the Middle East, numbering around 5-6 million. ${ }^{1}$ In contrast, the Maronites are a small community in terms of size. It is estimated that there are no more than 600,000 Maronites in Lebanon. Yet within Lebanon, they still make up over 20 per cent of the population, offering them a chance to have 
a significant impact on national affairs. ${ }^{2}$ A brief outline of the two communities will focus on the background and personality of the two patriarchs, the current concerns of the communities and the patriarchal response to these challenges. Finally, seven variables will be identified to help indicate the type of political role one would expect the patriarch to have.

\section{The Crisis of State Approach}

Religion is often perceived as becoming politicized when there is a crisis of state. Increasing awareness of the limits of modernization and subsequent disenchantment has resulted in questions of meaning and identity being given as much importance as material and economic issues. In the developing world, these crises take a different form from those experienced in the West. The failure to deliver development and democracy is widespread. Economic development has failed to keep up with population growth, leading to increasing domestic inequality. The state tends to be bureaucratic, inefficient and unable to respond to these problems. Modernization has not resulted in the expected benefits. According to Murden, 'For far too many Middle Easterners, modernization meant an urban experience of poverty, underemployment, poor housing and services, and few prospects'. ${ }^{3}$ This social crisis has been coupled with the failure to provide political participation. Instead, these states are often characterised by authoritarianism, patriomonialism and corruption.

Norris and Inglehart expand on these ideas in their hypothesis of secularization based on existential security. ${ }^{4}$ They argue that individuals expect the provision of 'human security' to be a key achievement of the state. Human security is defined as the lack of immediate risk to personal safety, for example, violence, natural/manmade disasters, disease and poverty. In poorer states, a significant proportion of the population is vulnerable to these threats. However, in post-industrial societies, conditions greatly improve as even the most vulnerable 
groups in society are covered to some extent by health and social services. While economic development is a prerequisite to attain this level of human security, industrialization alone is not enough. Without the transition to a post-industrial phase, socioeconomic inequalities pose an extremely visible threat to stability. Norris and Inglehart demonstrate that there is a general correlation between the removal of immediate risks and the decline of religiosity in a specific society. This fits into the Weberian view of the secularizing influence of wealth. However, this trend can also be halted or reversed if threats re-emerge such as natural disasters.

Applying this approach to the Middle East, most countries have experienced aspects of modernization. However, it has proved an uneven process and served to heighten socioeconomic inequality. The perception of vulnerability remains strong whether from violence or, more frequently, poverty. While the modernization process may have a mixed record, the region has clearly not reached the postmaterialist phase. The transition to a capitalist economy concentrating on the individual rather than the community has not occurred to the same extent as in the West. As religion tends to draw support from the community, it is unsurprising that religion continues to enjoy social significance in this society. In contrast to the numerous ideologies championed by regimes, religious institutions have remained steadfast and provided enduring values. People have turned to an indigenous and authentic identity that offers answers to the many concerns faced by them. Throughout this Muslim majority region, the response of many Muslims has been to support religious movements, which proclaim that Islam can provide a solution to these ills. The success of these organizations in fulfilling the duties of the state e.g. social and welfare services, ensures that politicized religion is seen as a viable alternative to the existing discredited policies.

The crises detailed above affect all citizens of the region, regardless of religious affiliation. For Christians, the failure of Arab nationalism to deliver its promises once in power was 
especially significant, as they had long depended on this route to attain equality. Instead, little progress towards full citizenship was made. Coupled with the failure to provide material benefits, Christian backing for the ideology they had long supported began to wane. The growth of political Islam as the main opposition to existing regimes heightened perceptions of vulnerability including increased communal tension and the potential curtailment of rights under an Islamic regime. Desperately requiring strong leadership, Christian communities tend to have weak and divided lay representatives who often lack legitimacy within the community. Thus with few alternatives, Christians, like their Muslim compatriots, have also turned to a religious institution to provide comfort during this difficult period. While certainly not a return to Christianity as the Middle Eastern Christian population has always retained its religious identity, it is evident that some communities expect the church to adopt a proactive role regarding their concerns. On a practical level, church organizations, like Islamist movements, have continued to provide social services for their communities, for example, schools, hospitals, employment aid and charity. The lack of political representation has also offered an opportunity for church leaders to undertake a more overt political role by acting as the main representatives of their community. The increased role of Eastern churches in politics does not have the same aims as Islamist movements. Rather than wishing to seize power or change the fundamental values of society, the core aim of this political activism is to articulate the rights and needs of the Christian communities.

Regarding the selected case studies, it is clear that both Egypt and Lebanon are experiencing crises of state which have particular resonance for the Coptic and Maronite communities respectively. The inability of the Egyptian government to tackle socioeconomic problems combined with the general feeling among Copts of alienation from political participation are factors which can be seen as contributing towards the strength of the Coptic Orthodox Church as the leading communal institution. At present, there are no credible rivals to the role of the 
church as civil representative of the community. In the early twentieth century, the Wafd party offered Coptic Christians a chance to participate fully with their Muslim compatriots to attain independence from the British. ${ }^{5}$ Coptic influence declined after the 1952 revolution partly as a consequence of nationalization measures. Few are selected as parliamentary candidates and even less are successfully elected. Most Coptic deputies are appointed by the president and two are usually included in the cabinet. ${ }^{6}$ Furthermore, many Copts perceive that neither these representatives nor government officials are willing to prioritise Coptic concerns. These include equality, political participation, church building regulations, conversions and violent attacks. Feelings of insecurity are heightened with each new incident of Christian-Muslim tension. ${ }^{7}$

Unlike Egypt, Lebanon has never enjoyed what could be termed a strong state. In fact, Lebanon experienced the ultimate crisis of state - civil war. Although the Maronite Church as an institution was also perceived as weak during the conflict years, unlike the state, it has recovered its legitimacy under Patriarch Sfeir. In post-war Lebanon, the main Maronite concerns centred on the Syrian influence, which was blamed for restricting the predominantly Christian opposition, curtailing Lebanese sovereignty and freedom and eroding the traditional position of the Maronite community. ${ }^{8}$ Ongoing instability since the assassination of former Prime Minister Rafiq al-Hariri has increased feelings of vulnerability especially amongst Christians who were the primary targets of a series of bomb attacks in Lebanon during 2005. The Lebanese confessional system also serves to accentuate religious ties in the political sphere, thus ensuring that religious identity remains a key factor. Therefore, it can be concluded that when the level of state crisis is high, the political situation of the country where the patriarch resides becomes the crucial factor. As will be seen shortly, if the patriarch is willing to undertake an active leadership role, members of the group are usually 
agreeable to delegating political representation to the church leaders who have tried to cater to their spiritual and material needs.

\section{Historical Experience}

The traditional authority given to the patriarch is also crucial in understanding community acceptance of the political activities of their spiritual head. The term patriarch was used to describe the head of the five major sees (Rome, Constantinople, Alexandria, Antioch and Jerusalem). ${ }^{9}$ The patriarch is more than the head of the church. He is the father of the flock, symbol of the faith and figurehead of the community. In the Coptic Orthodox case, loyalty to the patriarch led to the eventual establishment of an independent church. Through the strength of the monastic movement in the desert, the church in Egypt had enjoyed influence in international church affairs especially over doctrinal issues. The unity of the early church was shattered by doctrinal controversies in the fifth century. The power of the Egyptian church was challenged at the Council of Chalcedon in 451 when their decision at the previous council (Ephesus in 449) to depose the patriarchs of Antioch and Constantinople was repudiated. Instead, this council pronounced that Christ possessed two natures, divine and human, which were joined in one person. Many theologians in Egypt, Syria and Armenia rejected this definition. The church in Egypt remained loyal to the deposed patriarch of Alexandria and refused to recognise any patriarch imposed on them from Constantinople. This also illustrated the divide between the Hellenized elite who mainly resided in Alexandria and the rural majority who used the Coptic language. The term Copt comes from the Greek for Egypt - aigyptos. ${ }^{10}$ In this sense, the Coptic Orthodox Church can be regarded as the Egyptian national church. Its members continued to resist the increasingly violent attempts by the authorities to reunite the early church. The Arab conquest signalled the end of Byzantine persecution and the beginning of a new era. 
The Arab Conquest was also partly responsible for the formation of another Eastern Christian church. Not all Christians in the geographical area of Syria had rejected the teachings of the Council of Chalcedon. A group of disciples of a fourth century hermit Maron had founded a monastery in his memory. These monks were subject to persecution including the massacre of 350 monks in 517 by followers of Patriarch Severus of Antioch. ${ }^{11}$ Church historians claim that because the last Orthodox Patriarch in Antioch died in 609 and his successors resided in Constantinople, the Maronite community was in grave need of a leader. The vacant see was filled in the late seventh century. In this way, the Maronite monastic community evolved into a 'church' with its own hierarchy and ecclesiastical autonomy. ${ }^{12}$ Given the title of Maronite Patriarch of Antioch and All The East, the first patriarch John Maron is regarded as the founder of the Maronite Church. Having lost Byzantine protection either due to electing their patriarch without the consent of the emperor, or as some historians claim, due to their following of the compromise Monothelitist doctrine, John Maron was credited with winning a decisive battle against the Byzantine army. ${ }^{13}$ Continual conflict resulted in waves of emigration to the safety of Mount Lebanon. The attachment to this area as a territorial and historic homeland is a strong component of Maronite identity.

Both rites have historically had strong patriarchal authority, derived from a combination of canon law and tradition. In the Coptic tradition, the canons assert the importance of the leadership of the church. Although the election rite has varied in the past, the present system, which was agreed in 1957, aims to ensure that the elected candidate will enjoy the support of the community. An electoral committee choose three candidates from a wider list who are then drawn by altar lot. A fourth name is added, 'Jesus Christ the Good Shepherd' to prove to the faithful that the candidate has been divinely approved. ${ }^{14}$ Once elected, the Coptic Orthodox Patriarch enjoys supreme authority over the community. A vacancy arises only 
with the death of a patriarch : he cannot be removed from office. The Holy Synod is the highest ecclesiastical body in the church and is responsible for all church affairs. In theory, the patriarch governs the church in conjunction with the synod but due to the position attributed to the patriarch (who presides over its meetings), it cannot be described as an independent force. However, the patriarch does have to take into consideration the opinions of his community. This was institutionalised in the late nineteenth century with the establishment of the al-majlis al-milli (community council) which was instigated by the laity elite who wished to gain control of the financial and administrative affairs of the church. However, as Meinardus suggests, 'patriarchs always looked at the majlis al-milli as an organization which restricted their authorities'. ${ }^{15}$ Under republican governments since 1952, the activities of the council have been weakened in favour of the patriarch. Representatives are included in the electoral committee but members voted on to the council rarely differ with the church hierarchy, especially the patriarch. ${ }^{16}$ Although laity participation remains an important tradition in the Coptic Orthodox Church, such activities cannot be described as effective constraints on patriarchal authority. Finally, in most instances, once the patriarch is elected, the government has little involvement in church affairs. ${ }^{17}$ However, the patriarch must obtain recognition from the president and in extreme circumstances, this can be revoked as occurred in 1981.

Turning to the Maronite rite, the role of the patriarch in the Eastern Catholic Churches is defined in the 1990 Codex Canonum Ecclesiarum Orientalium (CCEO), the codification of canon law for these churches. The importance of the patriarch to the church has been clearly stressed. Canon 55 states, 'According to the most ancient traditions of the Church, already recognized by the first ecumenical councils, the patriarchal institution has existed in the church : for this reason a special honour is to be accorded to the patriarchs of the Eastern Churches, each of whom presides over his patriarchal church as father and head'. ${ }^{18}$ The 
patriarch enjoys executive and administrative powers and is the highest juridical authority for the community concerning personal statute laws. Although bishops must resign aged seventy-five, this is not applicable to patriarchs, hence illustrating the importance of the position. The main constraint on the Maronite patriarch is that final authority in Eastern Catholic churches lies with the pope - the supreme head of the universal church. This means that the Vatican is involved in all aspects of church affairs. The pope must be informed of a vacant see and patriarchal elections and has indirect influence on the nominations to the office. ${ }^{19}$ Furthermore, the patriarch and the synod are interdependent. The patriarch has the executive role as he convokes and presides over the synod while the synod enjoys legislative and judicial power. In conclusion, in both case studies, the patriarch exercises substantial authority. As this is derived from canon law, the patriarch enjoys legitimacy to an extent which cannot be replicated by other leaders. Using this as a foundation, the head of the church has the resources to provide both spiritual and civil leadership to the community.

The historical experience of Christianity in the Middle East has also proved influential in maintaining patriarchal authority. Eastern Christianity underwent a different historical process from that of the Western churches - one which denied it political power but allowed it to remain a key aspect of identity. It enjoyed only a short period of power - when it was declared the official religion of the Roman Empire in the fourth century until the Arab Conquest in the early seventh century. The conquest effectively halted the ability of Eastern Christianity to seek political power as the new empire was based on another religion - Islam. Yet, the temporal role of the patriarch was ironically reinforced through centuries of Islamic rule as the patriarch was identified as the civil leader of their community. Under Muslim rule, the Christians as ahl al-kitab (people of the book) became dhimmi (covenanted people). ${ }^{20}$ The different Christian communities in the region were treated as distinct groups with the patriarch held responsible for the conduct of the entire community. In general, the patriarch 
continued to enjoy authority over the internal affairs of the community on the condition that taxes were paid and that there was no interference in Islam - the state religion. In order to collect taxes, the patriarchs were given positions in the administrative system and allocated 'civil coercive authority' to attain this. ${ }^{21}$ This system allowed the Eastern churches to retain control over all aspects of life for their communities. Yet Eastern Christians had no possibility of attaining state power and thus escaped revolt against the church state system as experienced in Europe.

Under the Ottoman Empire, this practice of autonomy became institutionalised and known as the millet system. According to Pacini, 'The religious authorities of each millet acted both as representatives of the members of their millet and as intermediaries between the latter and central power in administrative matters' ${ }^{22}$ The Greek Orthodox Patriarch in Constantinople was responsible for all religious, civil, legal, educational and financial affairs in the Christian millet. ${ }^{23}$ Other heads of churches were also able to secure their position as the civil heads of their communities. The religious heads (excluding the Maronite patriarch who relied on French protection) were given a berat - legal recognition of their position. The geographical distance from Constantinople to Egypt and Lebanon allowed the Coptic Orthodox and Maronite patriarchs to continue to exercise de facto control of their community with little external interference from the Greek Orthodox.

In the Egyptian case, the development of an indigenous millet system illustrates the close connection between the Coptic Orthodox community and the Egyptian nation state.

Although nominally part of the Ottoman Empire, due to geographical location, the rulers of Egypt tended to enjoy autonomous power to an extent that allowed the notion of a distinct Egyptian identity to remain. ${ }^{24}$ Consequently, it was natural that the figures of the Sultan and the Greek Orthodox Patriarch of Constantinople would be replaced by the Egyptian ruler and the Coptic Orthodox Patriarch - the leader of the vast majority of Christians in Egypt. ${ }^{25}$ In 
most cases, the Coptic Orthodox patriarchs remained politically passive, preferring to concentrate on securing internal dominance within the community. For example, Patriarch Kyrillos VI secured presidential permission to build an agreed number of churches each year and was rewarded when the Nasser government abolished the al-majlis al-milli in 1962 (the main communal rival to patriarchal power). ${ }^{26}$ In exchange for these measures, the patriarch promoted loyalty to the government especially during the crises of 1956 and 1967, thus conforming to the traditional millet model of community relations.

In contrast, the Maronites did not live under strict millet conditions. This was mainly due to their isolation in their remote homeland of Mount Lebanon. Ottoman authority rarely penetrated deeply into this area, partly due to its remoteness and partly due to its tradition of being a safe haven for different minority groups for example, Maronites and Druze. Individual rulers remained relatively independent and in some cases, were favourable to the Maronite community. ${ }^{27}$ The patriarch did liase between the ruler and the community but without the sense of inferiority that was inherent in the millet system. ${ }^{28}$ Thus, the Maronite patriarch has always had a political dimension as the leader of the community. Patriarch Hoyek is considered a founding father of the modern state of Lebanon as he was instrumental in securing the establishment of Greater Lebanon under the French mandate at the 1919 Versailles Conference. Similarly, Patriarch Meouchi played an active role during the 1958 crisis in ensuring that opposition to the policies of President Chamoun did not descend into religious conflict. ${ }^{29}$ In conclusion, it can be seen that centuries of Islamic rule maintained and perhaps enhanced the civil authority of the Christian religious leaders in this region.

\section{Case Studies}

In both case studies, the incumbent in the patriarchal office has greatly influenced the development of his church and community. The future Patriarch Shenouda was born Nazir 
Gayed in 1923 to a middle class family in Assiut (Upper Egypt), graduated in History from Cairo University and was an army officer in the 1948 war against Israel. ${ }^{30}$ He became known as a theologian, journalist, orator and poet and was actively involved in the influential Sunday School movement. Entering monastic life in 1954 aged thirty-one, he remained for eight years until he was consecrated Bishop of Higher Theological Studies in $1962 .{ }^{31}$ According to Heikal, 'Shenouda was the outstanding representative of the new generation of militant monks, determined to change the Church from an isolated and backward institution into something more in tune with the contemporary world' ${ }^{32}$ One important activity was his weekly meetings - dars al-juma'a (lesson on Friday). His willingness to answer questions from ordinary members of the community often with humorous remarks not only illustrated the difference from the traditional clergy but also helped to ensure that he became well-known within the community. ${ }^{33}$ After the death of Patriarch Kyrillos VI in 1971, the forty-seven year old Shenouda was elected by altar lot having come second behind Bishop Samuel in the first stage of the elections. ${ }^{34}$

Similarly, the present Maronite patriarch has also been heavily involved in church activities throughout his life. Born in Rayfoun, Kesrouan in 1920, Nasrallah Sfeir studied Philosophy and Theology at the University of St. Joseph in Beirut. In 1950, he was ordained into the priesthood and served in his home parish of Rayfoun. From 1956 until 1961, he was professor of translation in literature and philosophy at the Maronite Brothers School in Jounieh. After being ordained Bishop of Tarsus in 1961, he served as a Patriarchal Vicar and continued to be the Secretary of the Maronite Patriarchate until his election in $1986 .{ }^{35}$ During this period, Nasrallah Sfeir was known for his moderate political views in contrast to the radicalization that affected many in the community as a consequence of the Lebanese civil war. Helmick states that this bishop represented those in the Maronite community who were 
not frightened of their Muslim neighbours but instead wished to restore harmonious relations. $^{36}$

Both patriarchs experienced a turbulent period during their early years in office. According to Ansari, Patriarch Shenouda represented the movement within the church hierarchy that was no longer willing to seek recourse through the traditional method of private representation of Coptic concerns to state officials. ${ }^{37}$ Instead, he saw it as his duty to adopt an assertive role to stand up for the collective rights of the community. This view coincided with a growing Islamization process under the presidency of Anwar Sadat. Coptic grievances regarding church building, discrimination and the legal system were not dealt with under the auspices of the traditional millet system. For example in 1972, the offices of a Christian society in Khanka, which was being used as an unofficial church due to the difficulties in gaining building permits, were set on fire. In response, Patriarch Shenouda sent one hundred priests and monks to protest at this incident and conduct prayers on the site. Consequently, the situation escalated when local Muslims attacked Christian property. ${ }^{38}$ Communal tensions were raised again in 1977 when the government attempted to introduce sharia law into the Egyptian legal system. ${ }^{39}$ Again, Patriarch Shenouda pursued a public approach by holding a Coptic Conference and calling for a five day collective fast to highlight the problems facing the community. The government abandoned the bill but violence against the Copts increased as many Muslims resented what they perceived as unnecessary Coptic interference in a Muslim only issue. Finally in 1980, amidst increased sectarian violence, the government amended the constitution to acknowledge sharia law as being the principal source of legislation. The patriarch cancelled the 1980 Easter celebrations and retired with the church hierarchy to a desert monastery. ${ }^{40}$ This was accompanied by demonstrations organised by Coptic émigrés during Sadat's visit to the United States. While these examples illustrated a break from the traditional co-operative political role of the church, they were mostly reactions 
to legislative proposals or attacks against Coptic property. However, this confrontational approach failed to resolve the underlying issues and served only to anger Sadat. Perceiving Patriarch Shenouda as a threat to his authority, Sadat publicly attacked the church hierarchy by accusing the patriarch of conspiring to establish a Coptic state in Upper Egypt and inciting sectarian strife. ${ }^{41}$ After clashes at Zawya al-Hamra in 1981, Sadat launched a crackdown on all opposition and banished Patriarch Shenouda to a monastery in Wadi Natroun. It was not until Christmas 1985 that his successor Hosni Mubarak gave permission for his return. ${ }^{42}$ Patriarch Sfeir also faced severe problems once elected as a consequence of the ongoing civil war. Both the community and church hierarchy were divided over what factions to support. As Patriarch Sfeir was not the candidate of the Lebanese Forces, the dominant Christian group at this time, he immediately faced opposition to his policies. Once elected, he tried to continue reconciliation measures sponsored by his predecessor. On a visit to Algeria in 1987, he met the leader of the Palestinian Liberation Organisation (PLO) Yasser Arafat and later declared that the Palestinian cause was 'sacred' ${ }^{43}$ This diplomacy did not gain a favourable response from many sections of the Maronite community who still blamed the Palestinians for the outbreak of violence in Lebanon. Patriarch Sfeir was instrumental in ensuring that the 1989 Document of National Understanding gained enough legitimacy in Christian circles to succeed. Known as the Taif Accord, it maintained the confessional system but sanctioned the presence of the Syrian army. ${ }^{44}$ However, this agreement was rejected by many ordinary Maronites, including the followers of General Michel Aoun (the caretaker Prime Minister). Incensed at the acquiescence of their patriarch to what they perceived as Syrian hegemony, the patriarch was jostled by demonstrators and consequently sought refuge in the Syrian occupied sector. ${ }^{45}$ This was the first time that the moral authority of the patriarch had been seriously challenged by the community. The patriarch publicly condemned the subsequent intra-Christian fighting, deeming it 'collective suicide' ${ }^{46}$ By the 
end of the civil war, the main aim of the patriarch was to oversee the rejuvenation of the Maronite church and as a consequence, the entire community.

The response of both patriarchs to the problems facing their respective communities can be divided into three interdependent areas - spiritual, social and political. Since the 1940s, the Coptic Orthodox Church has experienced a spiritual renewal that has revitalised the church. As one of the architects of this process, Patriarch Shenouda has been able to place the church at the centre of the community. Church attendance has increased massively to the extent that churches are full and extra services are held to accommodate the needs of the community. The ongoing monastic revival has energised the wider church. There has been a significant expansion in both the number of monasteries and monks. Monks are predominantly welleducated, often university graduates and aged between twenty-five and forty and this vocation has now become a model career for many Copts, especially the youth. ${ }^{47}$ The laity have also been incorporated into the organisational structure through work as deacons and church servants. ${ }^{48}$ Leisure time is dominated by the church. Activities include prayer groups, visits to monasteries and voluntary work restoring icons, churches and monasteries. The church has concentrated greatly on the youth. It is no surprise that the Sunday School movement plays an important role in educating the children on their faith considering its influential figures now occupy top positions in the church hierarchy. Similar to the Islamic revival, this Coptic renewal is also visible. Christian homes and shops frequently have religious symbols, for example, pictures depicting scenes from the bible, and women often wear jewellery shaped in a cross. The revival has led to emphasising a distinct Coptic identity. The study of the ancient Coptic language has been encouraged as a means to rediscover Coptic heritage. The Coptic Renewal has allowed the church to provide a space for Copts where they can fully participate. According to Hasan, 'By giving all Copts a role to play from their early teens on, the church has provided them with a compensatory status system and a chance of upward 
mobility outside of civil society' ${ }^{49}$ However, this appears to be at the cost of withdrawal from wider Egyptian society.

To a lesser extent, the Maronite Church has also undergone a spiritual renewal in the postwar years. Both the Vatican and the Maronite hierarchy have addressed the divisions within the church in order to rebuild communal unity. The Pope convened The Special Synod for Lebanon (1991-1995) and stressed the need for all Catholic communities in Lebanon to join together to attain spiritual renewal. It outlined the Papal vision of the Lebanese future - one where Christians and Muslims work together to rebuild their country. ${ }^{50}$ This was followed by the Apostolic Exhortation 'A New Hope for Lebanon' which was signed by the Pope during his visit to Lebanon in 1997. The Maronite Church also enacted its own initiatives for church renewal. After several attempts, the Maronite Synod was opened in 2003. It is the first time that members of the 'Maronite family' have been brought together from around the world to discuss the affairs of their church. The issues addressed include the identity, mission and role of the church, pastoral renewal and the diaspora. ${ }^{51}$ Following the precedent established at the Special Synod for Lebanon, representatives of other religious communities in Lebanon - Christian and Muslim - were invited to attend. The Maronite spiritual renewal is also apparent when examining the devotion to the saints. At the canonization of the nineteenth century monk Neamatallah Kassab Hardini in 2004, 50,000 Lebanese pilgrims travelled to Rome while thousands more attended celebrations in the Monastery of Kfifane. ${ }^{52}$ Thus, this focus on spirituality can provide solace for the Maronite community in times of difficulty.

The provision of social services has become an important part of the ministry provided by the two churches. These initiatives have allowed the churches to fill the vacuum left by the state. The Coptic Orthodox Bishopric of Public, Ecumenical and Social Services provides material assistance, educational classes, literacy programme and job training schemes. ${ }^{53}$ 
However, some critics such as the late influential monk Father Matta al-Maskeen raise concerns that these social services will attract Copts to the church for material not spiritual reasons. In the Maronite case, such services help to preserve Maronite identity. In the post war era, the church has tried to maintain its presence throughout the country by repairing institutions and supporting the return of refugees in areas that have been depopulated of Christians. Aware of the economic plight of the country, the church, particularly through the monastic orders, has continued its key role in education and health as well as providing land for affordable housing. While the hierarchy has tried to provide for the needs of the community, some Maronites have criticised these efforts as inadequate considering the extent of resources that the church possesses especially land and institutions. ${ }^{54}$

Finally, both patriarchs have chosen to fill the leadership vacuum by acting as the political spokesman of the community. Although Patriarch Shenouda attempted this during the Sadat era, there has been a change in methods as he has returned to the millet system of supporting the government in return for enjoying autonomy over the community. In interviews and prepared statements, he urges the government to reach out to disaffected Copts but praises initiatives that are perceived as aiming to address Coptic grievances, especially church building. Each new permit for construction or repair work is mentioned in al-Keraza (the church magazine) and accompanied by a message of appreciation to President Mubarak. ${ }^{55}$ Until recently, the church hierarchy did not support specific candidates or parties instead solely advising that the community should participate in national life. Yet, the patriarch controversially gave his full support to President Mubarak in the first presidential elections held in $2005 .^{56}$ Patriarch Shenouda has frequently complimented the president, stating that he is attentive to Coptic concerns. 'President Mubarak is an enemy of all sorts of extremism, bigotry and discrimination' ${ }^{57}$ This strategy illustrates the political astuteness of the patriarch as he is aware that while conditions may not be perfect, the Mubarak regime has proved 
relatively tolerant to the Coptic community, which could not be guaranteed under other candidates. Concerning Coptic electoral participation, the patriarch argues that if Copts continue to be unsuccessful at winning seats, it is no surprise that they are becoming politically apathetic. ${ }^{58}$ While the election of Youssef Boutros Boutros Ghali in 2000 was welcomed, the patriarch highlighted that this government minister needed two rounds to succeed even though he stood in a predominantly Coptic area.

On the issue of discrimination, Patriarch Shenouda has made a few selective comments. His preferred method of dealing with contentious issues (conversions and church building) appears to be through private discussions with officials. One notable exception was the Wafaa Constantine affair in December 2004. In brief, the wife of a Coptic Orthodox priest purportedly converted to Islam. Rumours immediately spread in the Coptic community that she had been abducted and forcibly converted. Protestors gathered outside the patriarchate in Cairo and clashed with security forces. Eventually, the woman was returned to the church authorities where she announced that she had not changed her religion after all. This was not before the patriarch had retreated to Wadi Natroun apparently in distress that the event had not been resolved quickly. ${ }^{59}$ The significance of this symbolic act cannot be overemphasised as this was exactly the type of method employed by Patriarch Shenouda during the tense Sadat years to draw attention to Coptic grievances. The next edition of al-Keraza concentrated on the disturbances and drew attention to general Coptic problems and the behaviour of the security forces. ${ }^{60}$ Finally, the patriotism of Patriarch Shenouda is often stressed. He rejects the idea that Copts are a minority, stressing that they are part of the Egyptian nation and warns against any outside interference regarding Coptic concerns. ${ }^{61} \mathrm{He}$ is a firm supporter of the Palestinian cause, banning Coptic pilgrimages to Jerusalem until the city is under Arab control. Clearly, the reign of Patriarch Shenouda has witnessed a more assertive political approach than normally associated with this position. Yet, although 
Patriarch Shenouda has been fairly successful in consolidating power within the community, this has not been transformed into tangible reforms from the government. Instead, concessions have primarily been cosmetic acts to placate the patriarch and the community. The conciliatory approach has fared little better than the assertive strategy in the Sadat era in meeting Coptic needs, especially regarding discrimination and security.

The Maronite patriarch has always tended to be more overtly political. This is especially true during the recent years of Syrian influence when the patriarch was instrumental in raising issues that others were unwilling to risk. Through sermons, media statements and monthly meetings of the Synod, the views of Patriarch Sfeir are made known. Many of these focused on the Syrian presence. The repeated calls for the withdrawal of Syrian troops were always placed in the context of regaining sovereignty as outlined in the Taif Accord. The bishops rejected the notion that the Syrian presence was necessary to ensure stability in Lebanon. 'When people say “it's either the Syrian army or chaos", it is an argument that simply does not stand up'. ${ }^{62}$ This campaign enjoyed limited success with the gradual redeployment of troops from Greater Beirut, Mount Lebanon and the North since June 2001. However, many Syrian troops remained in the Beqaa region and it was not until the developments set in motion by the assassination of Hariri in 2005 that a complete withdrawal took place. Patriarch Sfeir has also addressed the complex issue of political participation, calling for an electoral system based on small districts that would allow voters to directly affect the result. The bishops expressed their disappointment when the previous electoral system was retained for the first elections held after the Syrian withdrawal, warning that it would lead to negative reactions from Christians who would perceive that little had changed. ${ }^{63}$ The patriarch continues to condemn the political bickering, corruption and economic incompetence that has plagued Lebanese politics for decades. He is particularly scathing of continued Christian disunity. ${ }^{64}$ 
Like Patriarch Shenouda, the Maronite patriarch also emphasises the patriotism of his community, stressing that their vision of Lebanon is one of national unity and reconciliation where all Lebanese regardless of their sect can enjoy equal participation, representation and a decent standard of living. Indeed, almost all of the issues raised by the patriarch, particularly those concerned with daily life, are stated on behalf of all Lebanese. It is apparent that Patriarch Sfeir, like the majority of his predecessors, has continued to show an interest in Lebanese political affairs. Compared to the situation of the Maronite church and community in the late 1980s, a major achievement has been the ability of the patriarch to unite the Maronites and act as a rallying point. However, it is evident that the church has enjoyed few actual successes in attaining its goal of the restoration of Lebanese sovereignty and tackling Maronite grievances. Although Patriarch Sfeir has tried to exert his authority, this has not led to his domination of the community. The patriarch has understood that the political role of the head of the Maronite Church in contemporary Lebanon must concentrate on providing guidance to the community and the country at large rather than advocating radical measures to achieve these aims. Patriarch Sfeir has retained his traditional predominant role but this has not been transformed into credible temporal authority as exercised in the past.

\section{Variables affecting the Political Role}

Seven variables can be identified that help explain the political role of the present patriarchs of these two traditions.

1) The tradition and authority invested in the patriarch

Historically, the patriarch has been regarded as the leader of the community. They have used their authority to consolidate power. Once elected, the Coptic Orthodox patriarch exercises almost complete control over the church. Theoretically, the Maronite patriarch has less power due to the position of the Holy See, but in reality, the patriarch enjoys a predominant 
position in the community. Patriarchal authority alone is not indicative of a political role but it can be used to encourage its development.

2) The identity of the community

Both groups have a distinct established identity. The main distinguishing feature is its religious affiliation. The church tends to be the only institution that includes the entire community and enjoys legitimacy. While their religious identity is not incompatible with national identity, disappointment with the existing situation in terms of political participation and equality, have led to a more exclusive approach. Allowing the church to act as civil representative has led to the politicization of communal identity and left groups vulnerable to accusations of disloyalty to the nation state.

3) The existence of a distinct homeland

Both communities identify a specific territory as their ancestral homeland. They do not claim exclusive ownership, recognising that it is shared with other groups. The Coptic Orthodox Church is regarded as the Egyptian national church. The Maronite church is similar although one must recognise that there are other churches active in the country.

4) The willingness of church leaders to utilise their own institutions to cater to the needs of the community This has been an influential trend under both Patriarch Shenouda and Patriarch Sfeir. The needs of the community can be divided into three areas - spiritual, social and political. Both have experienced a period of spiritual revival. These have emphasised the distinct heritage of the community and help to fulfil the need for belonging, which many feel is not obtained within the national framework. Although social work has always been an element of Christian ministry, socioeconomic problems have made this aspect imperative. By providing welfare services, both churches have taken on many of the social responsibilities normally associated with the state. Thirdly, both leaders have sought to articulate the aspirations and 
grievances of their community. They have interpreted their position as head of the church to enable them to become the voice of the community. While all three aspects - spiritual, social and political appear intertwined, it would seem that the patriarch is unlikely to be regarded as a legitimate representative if the first two functions are not fulfilled.

5) The historical background and present political situation of the country

Religion has retained social significance in both Egypt and Lebanon. The views of religious leaders tend to be respected by governments and considered relevant by many sectors of society. The increased political role of the two spiritual chiefs is connected to the political situation. Few consider that their opinions are taken into account by the ruling elite. For the Coptic Orthodox, the disillusionment with the nationalist state is magnified because they had hoped that nationalism would allow them to obtain full citizenship, yet instead, the perception of discrimination remains. Concerning the Maronites, in contrast to their pre-war dominance, some of their privileges have been eroded, particularly in terms of political participation. This insecurity has been heightened by other factors. Both countries suffer from severe socioeconomic problems - poverty, unemployment, poor housing and services. The demographic context is also important. In numerical terms, both are minorites and in proportion to the size of the Muslim population, their percentage of the population is in decline. This adds to the perception of vulnerability and has led to the communities turning inwards to the traditional system of political representation through the patriarch.

6) The personality and views of the patriarch

The present patriarchs of the two churches studied have had an astounding impact on their respective churches. Both were involved in the inner workings of the institution before becoming patriarch. Both are charismatic personalities who have managed to revitalize not only their church but also their community. Both believe that it is their duty to voice opinions on national affairs. The Coptic Orthodox Patriarch is perceived as representing 
solely Coptic interests whilst the Maronite patriarch has been termed the patriarch of Lebanon as his statements often reflect concerns of ordinary Lebanese. This may reflect the different situation in the two countries where the Copts are a clear minority whereas the Maronites are one of several groups. The views of both patriarchs tend to correspond to the concerns of their communities. It is clear that any religious leader who becomes involved in political affairs has to walk a tightrope in order to satisfy the demands of a community without causing strife either internally or with the authorities or wider society. The patriarchs are prone to modifying their political strategies in accordance with developments in the country and community. Examples include the change of methods used by Patriarch Shenouda under the Sadat and Mubarak regimes or the stance of Patriarch Sfeir towards the question of the Syrian presence in post-war Lebanon.

7) The challenges to patriarchal authority

The response to the political role of the patriarchs has mostly been favourable. Generally, both communities have accepted that the patriarchs are motivated by their desire to safeguard the community rather than personal ambition. While some would prefer that the church concentrated solely on spiritual matters, there is awareness that the community needs leadership which at present, can only be delivered by the patriarch. From the community, challenges to patriarchal authority tend to be over the strategies followed. Elements of the Coptic community have become radicalized and are increasingly willing to defend their faith and church from perceived insults and threats as illustrated by the Wafaa Constantine affair. So far, the patriarch has been able to accommodate these but any return to assertive policies could have unwanted repercussions for the community. The Coptic diaspora also has the potential to articulate other views. As these are often articulated within a persecution discourse, their actions tend to have an adverse effect on communal relations in Egypt. In contrast, the main communal challenge to Patriarch Sfeir comes from the Maronite secular 
elite. The decline of Syrian influence in Lebanon has led to the return to politics of influential Christian leaders. Yet, the persistence of several rival factions, continued instability and the personal belief of the patriarch that it is his duty to give his opinion on political matters, suggests that he will continue to have a political role in Lebanon. The state authorities can also curb the political role of the patriarch. The Egyptian government has lent legitimacy to the patriarch by addressing the community through the millet system. In Lebanon, the significance attached to the patriarch is illustrated by regular visits to the patriarchate from politicians of all persuasions. Both patriarchs try to co-operate with their governments to a certain extent. At societal level, there is general acceptance of a religious leader undertaking civil representation on the understanding that the patriarch does not actually participate in the decision-making process. The patriarchs occupy an influential position but their ability to continue depends on events outside their control as they are vulnerable to changes.

\section{Conclusion}

This essay has sought to demonstrate that the political role of the patriarch can be explained by the political environment and historical experience of the communities. In both cases, religious identity has become more pronounced as a consequence of the difficulties faced by the nation state. This identity helps to maintain the cohesiveness of the community. Thus, it is natural that the leader of the institution that provides this identity would be given the opportunity to act as both the spiritual and civil leader of the group. Each church found itself in a strong position because of the extent of patriarchal authority traditionally ascribed to the religious head of the community. It would appear that the individual patriarch decides to a large extent what role he will play. In the two examples, the church hierarchies have used 
their position as the leading communal institution to offer the community stability and security by preserving group identity, providing for their material needs and articulating political concerns. Furthermore, the political situation of the country where the patriarch resides is crucial in determining what type of role the patriarch will have. In many cases, the involvement of the patriarch in political matters tends to be a reaction to developments in the country. The existence of a leadership vacuum (which is closely connected to domestic political events) also greatly enhances the ability of the patriarch to act as spokesman of the community.

The crisis of state environment would appear to provide the conditions that allow the patriarch to adopt this role. To a certain extent, the continuance of this role depends on the crisis of state conditions remaining. If these were to ease, alternatives to church representation could emerge. The Coptic Orthodox Church has more chance in resisting these changes. Both the government and society appear to have accepted the millet system as the natural method to manage communal relations. Yet regardless of the methods pursued, Patriarch Shenouda has failed to fully deliver the promises of Coptic equality, leaving space for future challengers. In contrast, the Maronite Church has more experience of operating in an environment characterised by secular leadership. However, the tradition of patriarchal authority means that both churches are likely to continue their efforts to represent the community. The difference would be that no longer would they enjoy the extent of influence exercised at present. In conclusion, while the crisis of state conditions continue to exist, the political role of the patriarch remains a crucial element when examining the significance of religious leaders in Middle Eastern politics.

1 For government statistics, see Christophe Asad, Geopolitique de l'Egypte (Bruxelles, Editions Complexe, 2002), p. 54

2 Jean-Pierre Valognes, Vie et Mort des Chretiens d'Orient (Paris, Fayard, 1994), p. 637

3 Simon Murden, 'Religion and the political and social order in the Middle East' in John L Esposito and Michael Watson (eds), Religion and Global Order (Cardiff, University of Wales, Press, 2000), p. 151 
4 Pippa Norris and Ronald Inglehart, Sacred and Secular : Religion and Politics Worldwide (Cambridge, Cambridge University Press, 2004), pp. 13-17

5 For information on Coptic participation in the Wafd, see Mustafa el-Feki, 'A Coptic leader in the Egyptian National Movement' International Studies Vol.22, No.1 (1985), pp.33-58

6 In the 2000 elections, 75 Coptic candidates were selected and 3 were elected including the present Minister of Finance Youssef Boutros Ghali. This minister was the only Copt to be elected in 2005.

7 While conversions are allowed in Egypt, the process for conversion to Islam is substantially easier. Rumours of kidnappings and forced conversions often arise but little evidence has been produced to substantiate these claims. The contentious legislation regarding building places of worship required presidential permission to gain a building permit, while there are few restrictions to build a mosque. A 1999 Presidential Decree led to an increase in the amount of permits but applications still took several years to be processed and even once accepted, were often blocked by local governments or security officials. Therefore, Christians often build churches without permits or try to convert Christian-owned property into a church. A further presidential decree in 2005 transferred authority to regional governors and requires them to justify their decisions within one month of submitting an application. Periodic communal clashes are often triggered by Muslim anger at Christian attempts to build or expand churches. Copts frequently complain that the security forces do not provide them adequate protection, perpetuators are rarely punished and that the underlying causes remain unsolved.

8 During the years of Syrian influence, the electoral system minimised the impact of voters from certain sects in some constituencies. This was intended to prevent any opposition success. As many of the opposition figures were Christian, this was perceived by Maronites as discrimination. The Christian community was also deprived of leaders who enjoyed populist support. For further details, consult Farid el-Khazen, 'Political Parties in Post-War Lebanon : Parties in Search of Partisans' Middle East Journal Vol.57, No.4 (2003), pp. 605-24

9 These five sees were chosen because of a combination of apostolic origins and political factors. Regarding the two sees relevant to the case studies, Alexandria was associated with the martyrdom of St. Mark while Antioch was an early centre of evangelisation.

10 Aziz S Atiya, A History of Eastern Christianity (London, Methuen \& Co Ltd, 1968), p. 16

11 George T Labaki, The Maronites in the United States (Beirut, Notre Dame University of Louaize Press, 1993), p. 6

12 Shafiq Abouzayd, 'The Maronite Church' in The Blackwell Dictionary of Eastern Christianity (Oxford, Basil Blackwell, 1999), p. 305

13 Valognes, Vie et Mort des Chretiens d'Orient, p. 371

14 Atiya, A History of Eastern Christianity, p. 123

15 Otto F Meinardus, Christian Egypt : Faith and Life (Cairo, The American University in Cairo Press, 1970), p. 25

16 Paul Sedra, 'Class cleavages and Ethnic Conflict : Coptic Christian Communities in Modern Egyptian Politics' Islam and Christian-Muslim Relations Vol.10, No.2 (1999), p. 228

17 Intervention by the government is normally at the invitation of the church. In 1954, members of a radical group Umma al-Qibtiya (The Coptic Nation) kidnapped the patriarch in protest at rampant corruption. The government secured his release but relieved the patriarch of his duties. See Theodore Hall Partrick, Traditional Eastern Christianity : A History of the Coptic Orthodox Church (Greensboro, Fisher Park Press, 1996), p. 156

18 Code of Canons of the Eastern Churches Latin English Edition (Washington, Canon Law Society of America, 1990), p. 25

19 Ibid. p. 33

${ }^{20}$ M A Muhibbu-din, 'Ahl al-kitab and Religious Minorities in the Islamic State : Historical Context and Contemporary Challenges' Journal of Muslim Minority Affairs Vol.20, No.1 (2000), p. 115

21 John D Faris, Eastern Catholic Churches : Constitution and Governance (New York, Saint Maron Publications, 1992), p. 7

22 Andrea Pacini, Christian Communities in the Arab Middle East : The Challenge of the Future (Clarendon Press, Oxford, 1998), p. 5

23 Ibid. p. 5

24 Although part of the Ottoman Empire, Egypt remained a distinct province. This became overt after the short-lived Napoleonic invasion (1798-1801) which led to the independent leadership of Muhammad Ali, known as the founder of modern Egypt. See Philip K Hitti, History of the Arabs $10^{\text {th }}$ ed (London, MacMillan, 1970), pp. 717-30

25 In contrast to the formal establishment of other millet, there is no precise date of the recognition of 
the Coptic Orthodox as a separate millet. Instead, it appears to have evolved in conjunction with developments in the formation of the Egyptian state to become the present millet system that is in operation in contemporary Egypt.

26 Partrick, Traditional Eastern Christianity, p. 165

27 An example of favourable relations is the rule of Emir Fakhr al-din II the Great (1590-1635). See Matti Moosa, The Maronites in History (Syracruse, Syracruse University Press, 1986), pp. 281-3

28 The Maronite patriarch was the only Christian spiritual leader who successfully avoided requesting the firman by using their ties with Western powers. As a consequence of the direct Ottoman occupation of Mount Lebanon during World War One, Patriarch Hoyek was forced to accept the firman in 1916. See Engin Deniz Akarli, The Long Peace : Ottoman Lebanon 1861-1920 (London, IB Tauris \& Co Ltd, 1993), pp. 165-74

29 For more information, see Ephraim Frankel, 'The Maronite Patriarch : An Historical Review of a Religious Za'im in the 1958 Lebanese Crisis' The Muslim World Vol.66, No.3 (1976), pp. 213-25

${ }^{30}$ Partrick, Traditional Eastern Christianity, p. 169

31 Otto Meinardus, Coptic Egypt : Ancient and Modern (Cairo, American University in Cairo Press, 1977), p. 13

32 Mohamed Heikal, Autumn of Fury: The Assassination of Sadat (London, Corgi Books, 1984), p. 171

33 P J Vatikiotis, The History of Modern Egypt (London, Weidenfeld and Nicolson, 1991), p. 421

34 S S Hasan, Christians Versus Muslims in Modern Egypt : The Century-Long Struggle for Coptic Equality (New York, Oxford University Press, 2003), pp. 245-6

35 CV of H.B. Cardinal Sfeir Maronite Patriarch of Antioch and All The East, www.bkerke.org.lb/Sfeir1e.html

36 Raymond G Helmick, 'Internal Lebanese Politics : The Lebanese Front and Forces' in Halim Barakat (ed), Toward a Viable Lebanon_(London, Croom Helm, 1988), p. 313

${ }^{37}$ Hamied Ansari, 'Sectarian Conflict in Egypt and the Political Expediency of Religion' Middle East Journal Vol.38, No.3 (1984), p. 398

38 Ibid. p. 400

39 The inclusion of the apostasy penalty was viewed by church leaders as affecting Christians because those who converted to Islam for convenience e.g. divorce or career ambitions, would be unable to return to Christianity. See John Eibner, Christians in Egypt : Church Under Siege (London, Institute for Religious Minorities in the Islamic World, 1993), p. 8

40 J D Pennington, 'The Copts in Modern Egypt' Middle Eastern Studies Vol.18, No.2 (1982), p. 174

${ }^{41}$ Eibner, Christians in Egypt, p. 18

42 This was due to the easing of communal relations and the realization that Copts regarded Patriarch Shenouda as the only legitimate leader of the church.

43 Valognes, Vie et Mort des Chretiens d'Orient, p. 394

44 Farid el Khazen, Prospects for Lebanon : Lebanon's First Postwar Parliamentary Election 1992 : An Imposed Choice (Oxford, Centre for Lebanese Studies, 1998), p. 13

45 Valognes, Vie et Mort des Chretiens d'Orient, p. 399

${ }^{46}$ Charles Winslow, Lebanon: War and Politics in a Fragmented Society (London. Routledge, 1996), p. 278

47 There were two hundred monks in 1950 which had risen to 2000 in 2000 . See John Watson, 'The Desert Fathers Today : Contemporary Coptic Monasticism' in Anthony O'Mahony (ed), Eastern Christianity : Studies in Modern History, Religion and Politics (London, Melisende, 2004), p. 114

48 Hasan, Christians Versus Muslims in Modern Egypt, p. 131

49 Ibid. p. 198

50 On the Maronite Synod, see Mounir Khairallah, 'La Synode Patriarcal Maronite : Periode Preparatoire (1985-2003)' Proche Orient Chretien Vol.53 (2003), pp.51-62

51 Final Communique of the First Session of the Patriarchal Synod, $21^{\text {st }}$ June 2003 www.maronitesynod.org/English/session1/final-communique.htm

52 The Daily Star, 'Lebanese monk among 6 granted sainthood', $17^{\text {th }}$ May 2004

${ }^{53}$ Sedra, 'Class cleavages and Ethnic Conflict', p. 226

54 Boutros Labaki, 'The Christian Communities and the Economic and Social Situation in Lebanon' in Andrea Pacini (ed), Christian Communities in the Arab Middle East : The Challenge of the Future (Clarendon Press, Oxford, 1998), p. 253

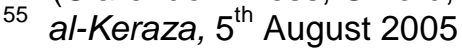
www.copticpope.org/downloads/eng-keraza/engkeraza05-08-2005.pdf 
56 al-Keraza, 22 ${ }^{\text {nd }}$ July 2005

www.copticpope.org/downloads/eng-keraza/engkeraza22-07-2005.pdf

57 Arabic News.com 'Pope Shenouda highlights Egypt's religious tolerance, improvements needed', $31^{\text {st }}$ May 2002

http://www.arabicnews.com/ansub/Daily/Day/020531/2002053135.html

58 Oriental Orthodox News Service 'An Interview with HH Pope Shenouda on El-Gezira TV Channel', March 2000 www.uk-christian.net/oons

59 BBC News, 'Egyptian Pope goes into seclusion', $20^{\text {th }}$ December 2004 http://news.bbc.co.uk/1/hi/world/4110861.st

60 al-Keraza, $17^{\text {th }}$ December 2004

www.copticpope.org/downloads/eng-keraza/engkeraza17-12-2004.pdf

61 al-Gawhary, 'Copts in the Egyptian Fabric', p. 21

${ }^{62}$ Middle East Times, 'Maronite-Shiite divide over Syrian presence in Lebanon', $13^{\text {th }}$ October 2000

63 The Daily Star, 'The Maronite Statement in Full', $12^{\text {th }}$ May 2005

${ }^{64}$ The Christian community was sorely divided at the 2005 elections. In the Mount Lebanon and Zahle districts, Aoun's Free Patriotic Movement allied with Michel Murr, a key figure in the previous pro-Syrian regime and defeated several Christian opposition politicians. See The Daily Star, 'FPM victory scores leadership positions of 21 -seat parliamentary bloc', $14^{\text {th }}$ June 2005 